\title{
Computational Biology, Protein Engineering, and Biosensor Technology: a Close Cooperation for Herbicides Monitoring
}

\author{
Giuseppina Rea ${ }^{1}$, Fabio Polticelli2 ${ }^{2}$ Amina Antonacci ${ }^{1}$, \\ Maya Lambreva ${ }^{1}$, Sandro Pastorelli ${ }^{1}$, Viviana Scognamiglio ${ }^{1}$, \\ Veranika Zobnina ${ }^{2}$ and Maria Teresa Giardi ${ }^{1}$ \\ ${ }^{1}$ Institute of Crystallography, National Research Council, Monterotondo Scalo, Rome, \\ ${ }^{2}$ Department of Biology, University Roma Tre, Rome, \\ 1,2Italy
}

\section{Introduction}

Application of herbicides has led to a marked increase in the productivity and preservation of agricultural products, as a result of which, cultural techniques for weed control, such as altering soil $\mathrm{pH}$, salinity, fertility levels or mechanical approaches, have been abandoned. These compounds are also used extensively in industrial sites, roadsides, ditch banks, irrigation canals, fence lines, recreational areas, lawns, railroad embankments, and power line rights-of-way, to remove undesirable plants that might cause damage, present fire hazards, or impede work crews. They also reduce costs of mowing procedures. However, due to the toxic effect, their control is carried out by a system of national registration which limits the manufacture and/or sale of pesticide products to those who have been approved (Montesinos 2003).

In this context, herbicides were classified into families based on their chemical similarity or, as proposed by the global Herbicide Resistance Action Committee (HRAC) group, according to their target sites and modes of action (Table 1). Standards and regulations for the classifications, labelling, and packaging of pesticides were first set up by the EUROPEAN ECONOMIC COMMUNITY (EEC) Council Directive 67/548/ in 1967.

At present the issue regarding herbicides is quite intricate, because according to the Food and Agriculture Organization (FAO), their exclusion would lead to a strong reduction in farming production; however, several toxic effects on biological systems associated with their use were proved by epidemiological and experimental studies (Waller et al., 2010; Roberts et al., 2010; Frazier 2007). After the first cases of animals poisoned by heavy utilization of herbicides, the monitoring of these compounds to avoid accumulation in the human body were strongly intensified. In particular in 1963, the World Health Organization (WHO) and FAO created the Codex Alimentarius Commission, which joined 173 signatories from the European Community (EC) countries in order to control the tolerable limits of pollutants in food. Twenty years later, the EC established a legal framework for the regulation of pesticides in all member countries. The Commission is responsible for the registration of pesticides actively used in all European countries. This authority is granted 


\begin{tabular}{|c|c|c|c|c|c|c|}
\hline Mode of action & & & Herbicide c & lasses & & \\
\hline $\begin{array}{l}\text { Amino acid } \\
\text { synthesis } \\
\text { inhibitors }\end{array}$ & $\begin{array}{l}\text { Amino acid } \\
\text { derivatives }\end{array}$ & Imidazolinones & Sulfonylureas & Sulfonamides & Thiopyrimidines & Glycines \\
\hline $\begin{array}{l}\text { Cell } \\
\text { membrane } \\
\text { disrupters }\end{array}$ & Diphenylethers & Bipyridiliums & & & & \\
\hline $\begin{array}{l}\text { Growth } \\
\text { regulators }\end{array}$ & Benzoics & Phenoxys & Pyridines & & & \\
\hline $\begin{array}{l}\text { Respiration } \\
\text { inhibitors }\end{array}$ & $\begin{array}{l}\text { Organic } \\
\text { Arsenicals }\end{array}$ & & & & & \\
\hline $\begin{array}{l}\text { Photosynthesi } \\
\text { s inhibitors }\end{array}$ & Triazines & Ureas & Nitriles & Miscellaneous & $\begin{array}{l}\text { Phenolic } \\
\text { compounds }\end{array}$ & Diazines \\
\hline $\begin{array}{l}\text { Lipid } \\
\text { biosynthesis } \\
\text { inhibitors }\end{array}$ & $\begin{array}{l}\text { Cyclo } \\
\text { hexanediones }\end{array}$ & $\begin{array}{l}\text { Arylphenoxy } \\
\text { propanoates }\end{array}$ & & & & \\
\hline $\begin{array}{l}\text { Root growth } \\
\text { inhibitors }\end{array}$ & Dinitroanilines & & & & & \\
\hline $\begin{array}{l}\text { Shoot growth } \\
\text { inhibitors }\end{array}$ & $\begin{array}{l}\text { Substituted } \\
\text { amides }\end{array}$ & Carbamothioates & & & & \\
\hline $\begin{array}{l}\text { Pigment } \\
\text { synthesis } \\
\text { inhibitors }\end{array}$ & Isoxazoles & Isoxazolidinone & Pyridazinones & & & \\
\hline
\end{tabular}

Table 1. Herbicide classification by mode of action.

by the Council of the European Community under Council Directive 91/414/EEC, adopted in 1991 and effective as of 1993.

Despite European policies to reduce the use of herbicides, EU statistics data for the period 1992-2003 showed that the annual consumption had not decreased (Eurostat Statistical Book, 2007). Hence, due to the occurrence of several toxic effects induced by herbicides, severe restrictions were adopted to safeguard particularly children, whose immature liver enzymes system is unable to detoxify these compounds. Concrete examples are the EU Baby Food Directives 2003/13/EC and 2003/14/EC, that fixed the maximum acceptable daily intake of pesticide residues in foods for infants and young children to a level lower than $10 \mu \mathrm{g} / \mathrm{kg}$.

Later in 2004, the production and use of persistent organic pollutants was forbidden by the United Nations Environmental Protection Programme (UNEP). Subsequently, the EC Regulation No. 396/2005 of the European Parliament and of the Council on Maximum Residue Levels (MRLs) of pesticides in products of plant and animal origin defined a new fully harmonized set of rules for pesticide residues, which became effective in 2008 . Recently, the new maximum residue levels of pesticides in food and feed of plant and animal origin was defined in the Regulation 2008/149/CE. In particular, for those herbicides most commonly found in surface and ground waters, allowed concentrations are $0.1 \mu \mathrm{g} / \mathrm{L}$ and $0.5 \mu \mathrm{g} / \mathrm{L}$, for a single pollutant and total pollutants, respectively. 
Nowadays the Directive 2009/128/EC of the European Parliament and of the Council is adopted to achieve the sustainable use of pesticides. Member States should monitor the use of plant protection products containing active substances of particular concern and establish timetables and targets for their use, in particular when it is an appropriate means to achieve risk reduction targets.

The United States (US) organization and legislation concerning herbicides sale and distribution are quite different from the above mentioned EC directives. The Environmental Protection Agency (EPA) is the agency primarily responsible for safety review and legal registration, regulating pesticides in the US.

In 1996, US Congress unanimously passed a landmark pesticide food safety law, called the Food Quality Protection Act (FQPA), which takes the protection of children into special consideration, and asked the EPA to conduct an Endocrine Disruptor Screening Program (EDSP) to monitor the effect of pesticides on the endocrine systems of living organisms. Globally, different policies were undertaken regarding pesticides use. For example in 2003, while the use of atrazine was banned by the EC, EPA studies affirmed that all triazine herbicides were without any harmful effect on the US population, infants or children (Sass \& Colangelo 2006). In 2006, the EPA also initiated a new program called "registration review" to re-evaluate all pesticides. The program's aim was to review the active ingredient of each pesticide every 15 years to ensure that all pesticide products in the marketplace could still be used safely. This process, called re-registration, considers the human health and ecological effects of pesticides and results in actions to reduce risks. The Agency completed more than $99 \%$ of tolerance reassessments by the end of 2006. The EPA issued the first test orders for pesticides concerning their potential effects on the endocrine system on October 29, 2009.

\section{Relevance of herbicide detection for environmental and health claims}

Herbicides are potent contaminants of ground and surface water as they are transported far away from the point of application via runoff and, as a result, contaminate otherwise pristine habitats, even in remote areas where they are not used (Readman et al., 1993; Relyea 2005; Haynes et al., 2000). In addition to their persistence, mobility, and widespread contamination of water, some herbicides brought about considerable ecological damage such as the disruption of predator-prey relationships, posing a threat to the survival of major ecosystems and a loss of biodiversity (Schneider 2009).

Another important aspect is herbicide resistance, an inherited ability of a plant to survive and reproduce following exposure to a dose of herbicide that would normally be lethal to the wild type. Herbicide resistance may occur naturally in plants as a result of random and rare mutations, or may be induced by genetic engineering (Shewry et al., 2008). Herbicide exploitation kills susceptible plants, allowing the herbicide-resistant plants to survive and reproduce without competition. The continuous use of herbicides allows the reproduction of resistant plants which then become dominant in the environment (Al-Ahmad et al., 2005; Murphy \& Lemerle, 2006). In addition, increasing problems with herbicide- resistant weed populations have increasingly occurred in countries with intensive agriculture cropping systems (Green \& Owen, 2010; Vila-Aiub et al., 2008). Changes in farming methods such as crop rotation, manipulation of planting time, hand weeding and application of herbicides with different target sites, are effective practices preventing resistance development. 
Regrettably, herbicides also negatively affect human health. According to the World Health Organization between 1 and 25 million people suffer of herbicide poisoning each year. It is estimated that as many as 20,000 people in the US will develop cancer every year due to herbicides residues in their food, but the number is much higher when we include the enormous number of people suffering from herbicide poisoning symptoms unknowingly. In this context, from a public health viewpoint, the prevention of diseases represents a priority and several investigations have been performed to reveal the presence of herbicides in water and food products (Lorenzin 2007; Sondhia 2010; Fussell et al., 2002; Cesnik et al., 2006).

In the literature many significant effects associated with exposure to herbicides have been documented; in particular, herbicides can cause short-term adverse health effects, called acute effects, as well as chronic adverse effects that can occur months or years after exposure. In addition, these effects are not necessarily exclusively caused by exposure to herbicides or other organic contaminants, but may be associated with a combination of environmental compounds which can have a synergistic effect with organic pollutants (Witte et al., 1995).

Several studies conducted on farmer populations, or on people particularly exposed to herbicides found high rates of eyes stinging, rashes, blisters, blindness, nausea, dizziness, asthma, diarrhoea and even death, as examples of acute health effects (Senthilselvan et al., 1992). On the other hand, examples of chronic effects include cancer, birth defects, reproductive damage, neurological and developmental toxicity, immunotoxicity, and disruption of the endocrine system (Kristensen et al., 1997; Fukuyama et al., 2009; Schreinemachers 2010; Turner et al., 2010; Ochoa-Acuña et al., 2009; Tanner et al., 2009).

Regarding neurological effects, herbicides can be potent neurotoxins. When people are exposed to neurotoxins they may feel dizzy, lightheaded, confused and may have reduced coordination and ability to think, as short-term effects. Long term exposure can result in reduced intelligent quotient, learning disability and permanent brain damage in people, especially children, who live in areas with high levels of herbicide contamination in water and food. Recent studies in several countries with a high use of herbicides indicate that there is an increasing incidence of carcinogenic effects, especially for children (Zahm \& Ward, 1998). National and international trends indicate that cancer rates have increased, including lymphocytic leukemia, childhood brain cancer, neuroblastoma, non-Hodgkin's lymphoma, testicular cancer, ovarian cancer and all cancers combined (Ries et al., 1998; Gurney et al., 1996; DeVesa et al., 1995).

Several herbicides are hormone disrupting chemicals, interfering with hormone biosynthesis, metabolism and resulting in a deviation from normal homeostatic control or reproduction. These compounds can cause physical birth defects, hormonal effects on the developing foetus or affect a child's functional capacities (Weselak et al., 2008). In addition, hormone disruptors are linked to many health problems including reproductive cancers (Fan et al., 2007). Twenty-four pesticides still on the market, including the herbicide atrazine, are known to be endocrine-disrupters, which are able to increase rates of endometriosis, hypospadias, undescended testicles and consequently testicular cancer, precocious puberty in girls, reduced sperm counts and fertility problems.

Given the latest statistics on the pathological effects caused by herbicides and the analytical problems of inadequate detection levels, as well as the insufficient quality control in many laboratories, the monitoring data are frequently a poor indication of the level of pollution in 
the environment (Guzzella et al., 2006). Key herbicides are included in the monitoring schedule of most countries, however the cost of analysis and the necessity to sample at critical times of the year (linked to periods of pesticide use) often preclude development of an extensive data set. In addition, several limits exist concerning the analyses related to the inadequate facilities, impure reagents, and financial constraints (Brena et al., 2005).

\section{Description of analytical methods and biosensors for herbicide detection}

This "unhealthy" scenario requires the challenging development of sensitive analytical control systems to reveal the presence of herbicides and protect humans and ecosystems. Properly assembled biosensors can satisfy these requirements, also providing reliability and flexibility of the assays (Giardi \& Pace, 2005).

A major difficulty in estimating environmental quality related to herbicides contamination is due to seasonal change of field application and the extremely low levels of the maximum admissible concentrations set by the EC. Nowadays, the data on herbicides pollution are still quite scarce since monitoring data are based on a few investigations carried out with methods able to detect relatively high concentrations of herbicides. Currently, in parallel to traditional analytical methods, novel detection systems have been already developed based on biosensor technology which provides rapid, inexpensive and reliable tools for herbicide monitoring and screening analyses, to answer the concern on this issue.

In this context, chromatographic techniques, such as gas chromatography (GC) and highperformance liquid chromatography (HPLC) with UV and/or mass spectrometry (MS) detection, surely represent the most trustworthy and common techniques used to monitor the presence of herbicides. The classical analytical techniques are unlikely to provide adequate sensitivity, while advanced instrumental methods are highly sensitive, but generally expensive, require skilled operators and are not easily amenable to on-site field testing. In addition, it must be emphasized that herbicides can greatly differ in chemical structure and chromatographic behaviour, so it is still impossible to apply a unique method to discriminate all of the different compounds that could be present in a real-world sample. Herbicides usually represent a very small fraction of the whole sample under investigation, so pre-treatments such as clean up and/or pre-concentration steps are required to make their identification possible. As a consequence, the qualitative and quantitative analysis of herbicide residues is time consuming and involves high costs.

Because of the large numbers of samples to be measured, the necessity of expensive equipment, organic solvents and laborious sample preparation, the development of a fast, automated and inexpensive test is of great interest. These concerns encouraged researchers to seek out alternative methods providing the desired analytical information.

The utility and high specificity of immunochemical technology for the detection of organic molecules has been well established in various research applications. In a study by Gascon and co-workers (1997), an ELISA analysis was developed for the detection of atrazine with a very low limit of detection, taking into account the European regulations for water and food. Chouhan and co-workers (2010) also reported a sensitive chemiluminescence (CL)-based immunoassay technique based on dipstick and flow injection analytical formats for the detection of atrazine.

In recent years, the development of new advanced methodologies for rapid, inexpensive and in field environmental monitoring based on biosensing devices represents a promising research challenge. Biosensors, following IUPAC definition (Thevenot et al., 1999), are 
devices able to provide quantitative analytical information exploiting a biological recognition element linked to a transduction system. They consist of three parts, as depicted in Figure 1. The first element is the biomediator (a biomimic or biologically derived material e.g. tissue, microorganisms, organelles, cell receptors, enzymes, antibodies, nucleic acids, and biological sensitive elements created with genetic engineering), the second element is the transducer or the detector (physicochemical, optical, piezoelectric, electrochemical, etc.) that transforms the signal resulting from the analyte's interaction with the biological element into another signal that can be measured and quantified; the third element is the associated electronics or signal processor, responsible for the output of the results in a userfriendly way (Cavalcanti et al., 2007). Biosensors require immobilization of biological elements on the surface of the sensor (metal, polymer, glass, etc.) using physical or chemical techniques. According to a recent report on the biosensor market, titled "Biosensors in Medical Diagnostics: A Global Strategic Business Report" published by Global Industry Analysts Inc., the global market for biosensors and other bioelectronics has grown from $\$ 6.1$ billion in 2004 to $\$ 8.2$ billion in 2009, at an AAGR (average annual growth rate) of about $6.3 \%$, and it is projected to increase still further in 2011 (RB-159R Biosensors and Bioelectronics report).

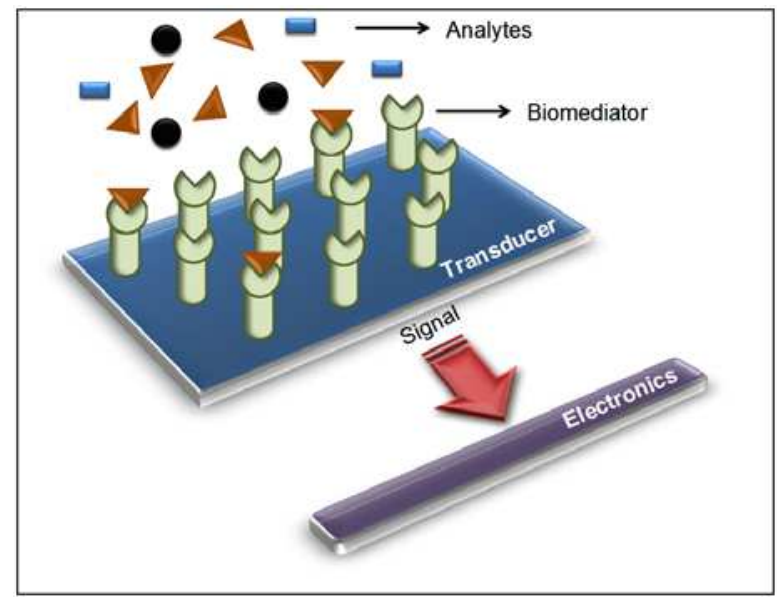

Fig. 1. Schematic representation of typical biosensor's components and activity mode.

A significant number of biosensors were designed, implemented and tested by several research groups with the aim to develop suitable methodologies with the best features in terms of versatility, stability, life-time and long-term activities, sensitivity and selectivity, detection limits, linear range, reproducibility and low cost.

In 1993 McArdle and co-workers described an amperometric biosensor incorporating the enzyme tyrosinase for the detection of the inhibiting herbicide atrazine. A similar electrochemical biosensor was developed by Mazzei and co-workers (1995), based on a plant tissue bioelectrode. In 2002 Shao and co-workers developed a cyanobacterial-based biosensor able to detect herbicides and other environmental pollutants. A magnetic nanoparticle-based biosensor incorporating alkaline phosphatase enzyme was proposed by Loh and co-workers in 2008 and applied to the determination of the herbicide 2,4dichlorophenoxyacetic acid (2,4-D). 
Studies in the framework of the development of biosensors for the detection of environmental pollutants exploit photosynthetic microorganisms or parts of them, such as thylakoids. Photosynthetic systems are naturally-occurring anisotropic supramolecular arrangements of proteins and small molecules that are able to harvest light energy and funnel it towards building up biomass and releasing oxygen. For these purposes, photosynthetic organisms are equipped with multi-enzymatic complexes embedded in thylakoidal or free membranes known as photosystems. The hierarchical organization of these pigment-protein complexes is at the basis of their unique efficiency. Functional and structural knowledge of photosynthetic systems has been steadily increasing, and as a result, fundamental and applied research have made it possible to integrate biological photosystems or their functional sub-structures into artificial assemblies in order to get them to carry out their tasks in a controlled environment for specific applications. Biosensors and nanobiosensors for the detection of herbicides fall into this category.

In detail, Photosystem II (PSII) is the multienzymatic chlorophyll-protein complex located in the thylakoid membrane of algae, cyanobacteria and higher plants (Figure 2). PSII is an integral part of the electron transport chain that catalyses photosynthetic primary charge separation. This protein complex consists of over 25 polypeptides, which make up the lightharvesting chlorophyll protein complex, the reaction centre and the water-splitting system, also called the oxygen evolving complex. The scaffold of the PSII reaction centre (RC) is formed by two protein subunits, D1 and D2, each composed of five transmembrane a-helices (named from A to E) with their $\mathrm{N}$ - and C-termini exposed to the stromal and

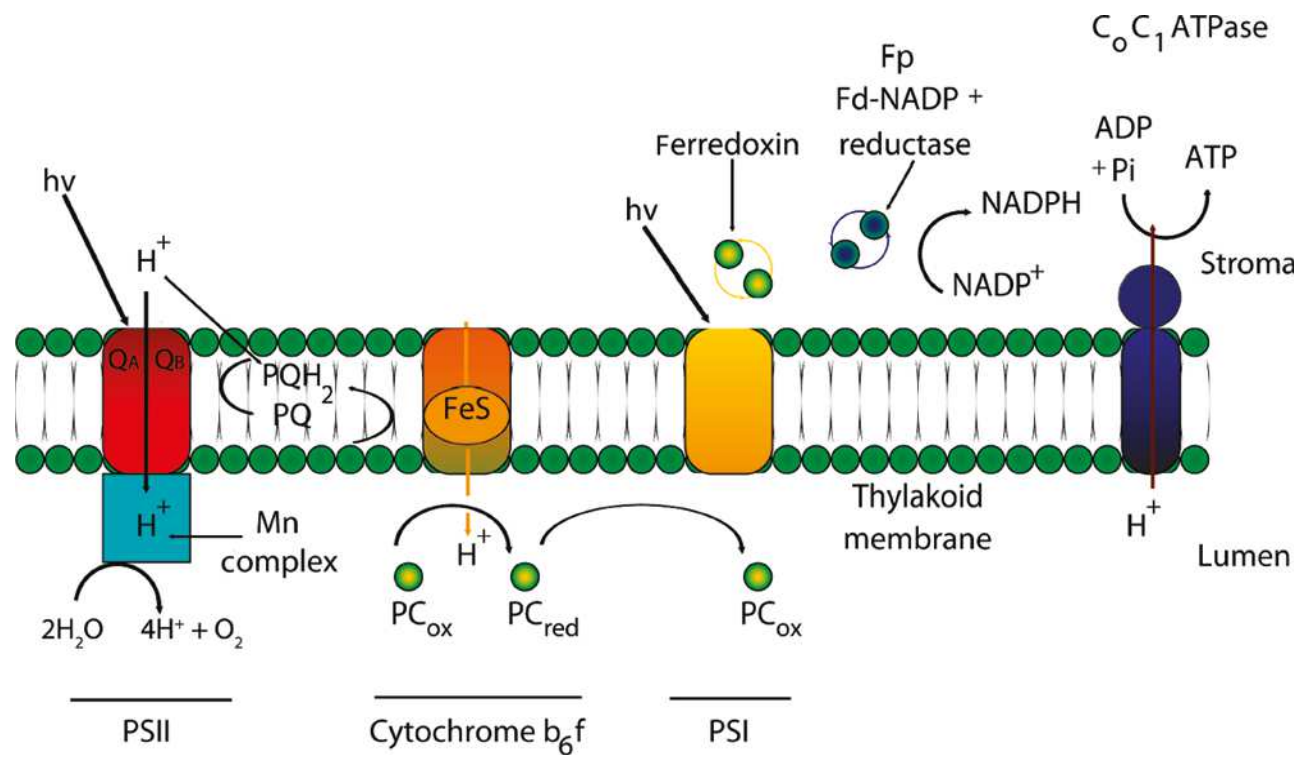

Fig. 2. Model of the photosynthetic membrane of plants showing the electron transport components (cross-sectional view). The complete membrane forms a vesicle. The pathways of electrons are shown by solid arrows. Photosystem II (PSII), photosystem I (PSI), and cytochrome $\mathrm{b}_{6} \mathrm{f}$ complexes, all involved in the electron transfer chain, are also shown (Buonasera et al., 2010). 
luminal sides, respectively. All the photosynthetic redox active components are located within the D1-D2 heterodimer, including the plastoquinones $\mathrm{Q}_{\mathrm{A}}$ and $\mathrm{Q}_{\mathrm{B}}(\mathrm{PQs})$ (Ferreira et al., 2004; Loll et al., 2005 a).

\section{Atrazine: a case study, exploitation and mode of action}

Most herbicides introduced in agriculture during the last 40 years impede chloroplast functions. The inhibitors of the photosynthetic reactions (urea/triazines and phenolic herbicides) comprise more than half of all commercially available herbicides of the 70's. Among them, atrazine has been a cornerstone for high-yield crop production, mostly in corn, sorghum and sugar cane farms for the last 50 years (http://www.atrazine.com). Atrazine, 2-chloro-4-(ethylamine)-6-(isopropylamine)-s-triazine, is a symmetric triazine. It is a soil-applied herbicide, which is actively absorbed by the roots, transported via the apoplastic system and accumulated mainly in leaf margins and tips (Hilton et al., 1976; Bouldin et al., 2006). Inside the cells, it readily penetrates and accumulates into the chloroplasts probably until an equilibrium concentration is attained between the chloroplast and the cytoplasm (Shimabukuro \& Swanson, 1969). Atrazine is selective and highly effective in the pre- and post-emergence control of a broad range of yield-robbing weeds; it is safe to the crop and fits in a variety of farming systems; it is the most widely used herbicide (except in EU since 2004) in conservation tillage systems, preventing soil erosion. Studies on weed control in corn plantations published in the North Central Weed Science Society Research Report showed that despite the availability of many new herbicidally active ingredients, corn yields with atrazine continue to be higher than with non-atrazine treatments (Fawcett 2008). This analysis assembled the data accumulated over a period of 20 years, from 1986 to 2005, including 236 relevant studies with a total of 5871 qualifying treatments. For the entire 20 -years period, the average yield with atrazine was $5.1 \%$ higher than without atrazine. In addition to all the advantages mentioned above, its low price also contributes to the widespread exploitation. As an example, according to the National Agricultural Statistics Service survey, the average US atrazine rate used in 2005 was 1.13 $\mathrm{lb} / \mathrm{acr}$ (or $1.27 \mathrm{~kg} / \mathrm{ha}$ ) and the cost of atrazine per acre was only $\$ 2.46$ (or $\$ 6.08 / \mathrm{ha}$ ) compared to $\$ 12.34$ per acre (or $\$ 30.49 /$ ha) for the average cost of 14 alternative broadleaf control herbicides in corn cultivation (Fawcett 2008). Considering the income from the increased corn yields and the low herbicide cost, for 2005 the study estimated a total US benefit for farmers of about $\$ 1.39$ billion. A similar estimation of atrazine utilization rate and its significance in cornfield production, based on analyses of US weed management systems, can be found in numerous research papers (Swanton et al., 2007; Williams et al., 2009; Williams et al., 2010).

Atrazine was registered for use in the United States in 1959 (US EPA, 1994). Because of its high water solubility and intensive utilization, it is the most common herbicide found in rivers, streams and groundwater at concentrations that very often exceed the MRL imposed by several European directives, even when used appropriately (Cox 2001). This set in motion the process for a regulatory ban in 2004 which became effective one year later in all EU countries (Ackerman 2007). Nonetheless, atrazine is still present in over $20 \%$ of the 3000 sites analysed in Italy (Paris et al., 2009).

However, in 2006 the EPA completed its re-registration eligibility process and still allowed atrazine use. Lately, the EPA has started broad re-evaluation of human health and ecological risk assessments associated with atrazine (US EPA, 2009). Nonetheless, atrazine remains one 
of the most widely used herbicides in North America and is used in more than 60 countries around the world - in Africa, North and South America, Asia and the Middle East.

The initial investigations on the possible mode of action of the photosynthetic herbicides (urea/triazines- and phenol-type), and in particular atrazine, performed intensively during the 50-60's of the last century, showed that they inhibit the Hill reaction in isolated chloroplasts (Moreland et al., 1959; Moreland \& Hill, 1962). It appeared that the triazines and urea-type herbicides had a similar mode of action, but it was still uncertain at that time. Based on the herbicide-induced stimulation of the chlorophyll $a$ fluorescence signal, Duysens and Sweers (1963) postulated that the herbicide inhibits the re-oxidation of primary quinone acceptor of PSII - $\mathrm{Q}_{\mathrm{A}}{ }^{-}$. Subsequently, it was shown that the photosynthetic herbicides block the PSII electron transport immediately after the $\mathrm{Q}_{\mathrm{A}}$ and the interruption of the electron transport occurs as a consequence of the herbicide binding to, at that time, an unknown protein in the chloroplast thylakoid membranes (Forbush \& Kok, 1968; Pfister \& Arntzen, 1979). The discovery of the first triazine-resistant plant (Senecio vulgaris) brought to light evidence that the resistance is due to alteration in the primary target, but not in the uptake, translocation or degradation metabolism of the herbicide (Pfister et al., 1979). The related protein was identified by means of photoactive herbicide derivatives, which under UV irradiation covalently bind the target protein. In this way, it was shown that azidotriazin binds to a $32 \mathrm{kDa}$ protein - the D1 protein of PSII (Pfister et al., 1981). In the beginning of the '80s it was believed that the photosynthetic herbicides inhibit the PSII electron transport allosterically (reviewed by Van Rensen 1982; Renger 1986). Tischer and Strotmann (1977) and later on also other groups (Oettmeier \& Masson, 1980; Haworth \& Steinback, 1987; Oettmeier et al., 1987; Giardi et al., 1988) demonstrated competitive binding between different herbicides. Vermaas et al. (1983) found that the binding affinity of atrazine sharply decreases when the $\mathrm{Q}_{\mathrm{B}}$ site is occupied by azidoquinone. The herbicide affinity to D1 depends on the redox state of $Q_{B}$; it is high when the $Q_{B}$ is in the oxidized state and weakly bound to the $\mathrm{Q}_{\mathrm{B}}$-pocket, and low when $\mathrm{Q}_{\mathrm{B}}$ is in the semi-reduced state and tightly linked to D1 (Lavergne 1982). These findings suggested a competitive binding between the herbicide and the PSII electron acceptor $\mathrm{Q}_{\mathrm{B}}$.

Nowadays it is widely accepted that herbicides such as diuron and atrazine block the electron transport between the primary $\left(\mathrm{Q}_{\mathrm{A}}\right)$ and the secondary $\left(\mathrm{Q}_{\mathrm{B}}\right)$ quinones of PSII by competitive substitution of plastoquinone in the $\mathrm{Q}_{\mathrm{B}}$-site of the $\mathrm{D} 1$ protein. An initial model of the herbicide-binding region and the orientation of the molecule in the binding site was developed by Trebst $(1986,1987)$. Later, a number of additional models were developed that described in more details the topology of the $\mathrm{Q}_{в}$ region and the possible herbicide/D1 interactions (Xiong et al., 1996; Lancaster \& Michel, 1999; Kern \& Renger, 2007). More recently an additional quinone binding site, named the $\mathrm{Q}_{C}$ site, has been identified, shedding light on the possible mechanism of quinol-quinone exchange which would involve a quinone entry tunnel and an additional/alternative quinol exit tunnel (Guskov et al., 2009). The above mentioned models are based on molecular modelling and X-ray diffraction studies of the structure of the RC of the bacterium Rhodopseudomonas viridis and of the PSII of cyanobacterium Thermosynechococcus elongatus, which are homologs of eukaryotic PSII. The $\mathrm{Q}_{\mathrm{B}}$ site is formed between the $\mathrm{D}$ and $\mathrm{E}$ trans-membrane helices of D1 protein, from Gly207 down to Phe274 aminoacid residues, and the plastoquinone forms directly hydrogen bonds with Ser264, His215 and Phe265 (Kern \& Renger, 2007). Lancaster and Michel (1999) performed a detailed study on the atrazine interaction with the bacterial RC in 
Rhodopseudomonas viridis. According to their model, the atrazine molecule is bound to the RC protein directly by three hydrogen bonds (Ile, Ser and Tyr residues) and indirectly via water molecules by four other hydrogen bonds. They emphasized the role of the orientation of the triazine molecule inside the RC binding site for the magnitude of the herbicide toxicity. The atrazine and the plastoquinone bind to overlapping, though not completely identical, regions localized in the common domain, but both target the serine aminoacid residue (Lancaster \& Michel, 1999). Additional information about the aminoacids involved in the herbicide/ $\mathrm{Q}_{\text {в }}$ pocket interactions was obtained from analyses of herbicide resistant or sensitive mutants. All 77 identified mutations in the PSII reaction centre D1 protein in cyanobacteria, algae and higher plants conferring herbicide resistance or sensitivity are localized in the region encompassing Phe211-Leu275 (Oettmeier 1999). Among them, 27 mutations consisted of Ser264 replacement, a finding in agreement with the well accepted concept that this aminoacid is the principal binding target of triazines and urea type herbicides. Other frequently cited aminoacid substitutions resulting in changes in the atrazine/D1 interaction are localized on Ala at positions 250 and 251, 8 and 9 mutations, respectively (Oettmeier 1999; Johanningmeier et al., 2000). The increasing number of data coming from atrazine resistant/sensitive mutants and the advances in the computation of structure design and modelling could significantly expand our knowledge on herbicide and PSII reaction centre interactions (Rea et al, 2009).

\section{Relevance of bioinformatic tools. Molecular docking, binding energy calculation and molecular dynamics}

In silico studies of macromolecular systems are becoming increasingly useful and reliable with the improvement of our knowledge of their physico-chemical properties and with the availability of more powerful hardware resources.

Nowadays, structural bioinformatics tools coupled to modern molecular biological techniques allow the tailoring of macromolecules as high affinity receptors for organic compounds of biomedical/environmental/industrial relevance to be used as biosensing devices for these compounds. In this framework, in the absence of high-resolution crystal structures, molecular docking techniques allow prediction of the binding site and mode of action of a given molecule to a macromolecule, a first step towards the rational redesign of the macromolecule to build an efficient biosensor. Several docking packages can also calculate the ligand-macromolecule interaction energy allowing the in silico evaluation of a macromolecular system affinity for a given ligand, and the effect of point mutations on this parameter. Energy minimization and molecular dynamics simulations constitute complementary and, to a certain degree, alternative methods to evaluate the affinity of a macromolecule for a ligand. In fact, energy minimization techniques represent a fast method to refine the putative complexes obtained by molecular docking and to predict the ligandmacromolecule interaction energy. An example of such an application is recent work carried out in our lab in which a large number of mutants of the PSII proteins D1 and D2 were generated in silico and the atrazine binding affinity of the mutant proteins was calculated by a combination of molecular docking and energy minimization techniques, to predict mutations able to increase PSII affinity for atrazine (Rea et al., 2009). The validation of the computational approach through comparison with available experimental data confirmed the efficacy of this approach. In addition, the production and characterization of one of the 
predicted mutants confirmed an increase in atrazine affinity for the D1-D2 heterodimer of one order of magnitude, with evident benefits for PSII-based atrazine biosensing applications (Rea et al., 2009).

A different approach is taken by molecular dynamics (MD) simulations. MD simulations are a powerful tool to study the evolution of a protein conformation in response to various stimuli, such as substrate/ligand binding, site directed mutagenesis, etc.. In the case of protein inhibitors, as is the case with herbicides, MD simulations provide essential information regarding the relevant interactions established by the inhibitor with the protein moiety and can guide the design of novel, more powerful inhibitors. However, when a given protein system is used in biosensing applications the reverse strategy can also benefit from molecular dynamics studies. In this case, rather than using simulations to design better inhibitors, MD simulations can provide an atomic level view of the protein-inhibitor interactions and guide the design of site directed mutants aimed at improving the affinity of the protein system for the inhibitor in order to improve its "fitness" for biosensing applications.

In this framework, MD simulations of PSII in the presence of herbicide inhibitors help to define the details of the molecular interactions stabilizing the herbicide-PSII complex and to pinpoint possible binding pocket modifications that could lead to an increased binding affinity.

\section{Molecular dynamics simulations of PSII-atrazine complex. Relevance for biosensor applications of PSII}

As already detailed above, atrazine is known to bind in the eukaryotic D1 protein region encompassing residues Phe211-Leu275, that partially overlap the $\mathrm{Q}_{\mathrm{B}}$ binding pocket (Giardi et al., 1988; Oettmeier 1999). Analysis of mutations conferring herbicide resistance or sensitivity indicated that Ala 250, Ala251 and Ser264 are located close to the atrazine binding pocket and probably directly interact with it (see above, Oettmeier 1999; Johanningmeier et al., 2000). Using this information, in the previous study cited above we obtained a molecular view of the atrazine-D1 interactions using a combination of molecular docking and energy minimization techniques (Rea et al., 2009). As shown in Figure 3, the model we obtained is in good agreement with the available mutational data in which atrazine is predicted to bind in a pocket made up by residues $211-218$ on one side, residues 251-255 on top and residues 264-275 on the opposite side, the same pocket hosting the $Q_{B}$ ring in the available crystal structure of Thermosynechococcus elongatus PSII (Loll et al., 2005 b). In the attempt to verify the reliability of this model and to refine the structure of the atrazine-PSII complex, we recently undertook MD simulations of the whole PSII macromolecular complex embedded in a lipid bilayer in the presence of atrazine. The Thermosynechococcus elongatus PSII crystal structure contains two macromolecular complexes in the asymmetric unit. However, it has been recently demonstrated that the in vivo functional PSII unit is composed of a single macromolecular complex (Takahashi et al., 2009). Thus MD simulations were carried out on the "monomeric" PSII macromolecular complex. Methodological details can be found in Table 2.

The atrazine molecule was placed inside the $Q_{\mathrm{B}}$ binding pocket in a such way that the following residues were found within $4.0 \AA$ distance from the molecule: His215, Leu218, His252, Phe255, Gly256, Ser264, Phe265, Leu271 and Phe274 (Rea et al., 2009). A hydrogen bond between the nitrogen atom of the ethylamino moiety (N5) of atrazine and the backbone amide group of Phe265 was possible for such a conformation. 




Fig. 3. Schematic view of the atrazine binding pocket within the PSII D1 protein obtained by docking simulations and energy minimization techniques (for details see Rea et al., 2009).

\begin{tabular}{ll}
\hline \multicolumn{1}{c}{ Starting structure } & T. elongatus PSII (3.0 A resolution, PDB entry 2AXT) \\
\hline MD simulations package & GROMACS v. 4.0.7 (Van der Spoel et al., 2005) \\
$\begin{array}{l}\text { Protein subunits force field } \\
\text { Cofactors force field }\end{array}$ & AMBER 99SB (Wang et al., 2000) \\
$\begin{array}{l}\text { Cofactors charges calculation } \\
\text { method }\end{array}$ & General AMBER force field (Wang et al., 2004) \\
Charge fitting and & \\
parametrization & Antechamber (Wang et al., 2006) \\
Membrane bilayer & \\
MD simulations total time & Pre-equilibrated DOPC bilayer model (Siu et al., 2008) \\
Time step & $10 \mathrm{~ns}$ \\
Temperature & $2 \mathrm{fs}$ \\
\hline
\end{tabular}

Table 2. Methodological details of MD simulations of the PSII-atrazine complex.

Already during the energy minimization run, additional hydrogen bonds between the aromatic ring nitrogen (N2) of atrazine and the amide group of Phe265, and between the ethylamino group (N5) of atrazine and the hydroxyl group oxygen of Ser264 were formed as well. Overall, only small changes of the atrazine position with respect to the position of the amino acids forming the active site of the starting conformation took place at this stage. 
During the MD simulation run, atrazine changed substantially its position within the $\mathrm{Q}_{\mathrm{B}}$ binding pocket (Figure 4).

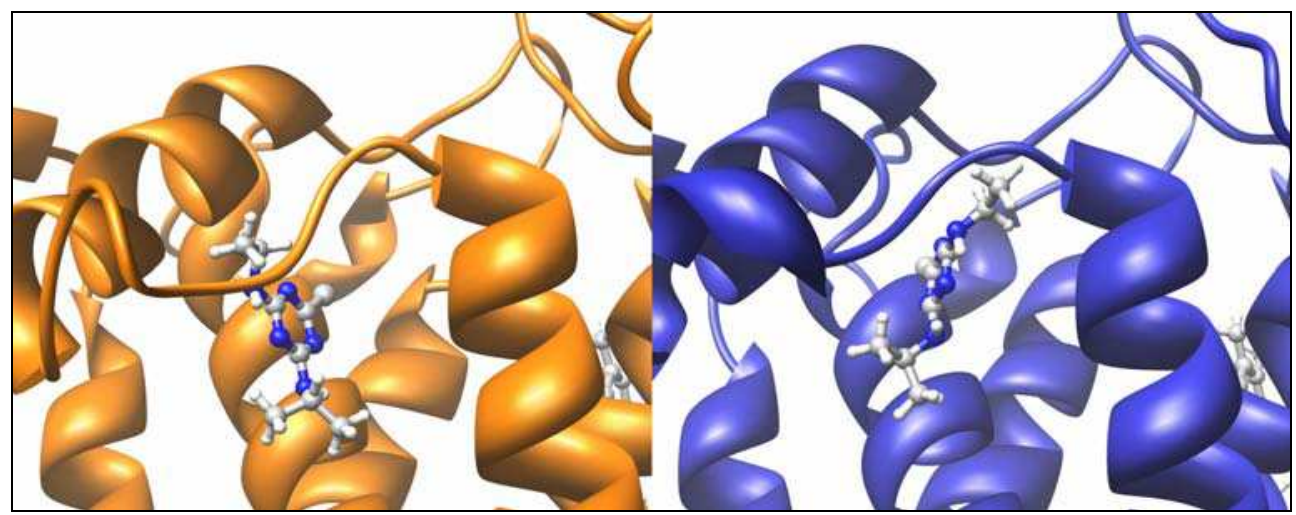

Fig. 4. Schematic representation of the atrazine-PSII complex initial structure (orange) and final structure (blue) after 10 ns MD simulations.

In particular after $10 \mathrm{~ns}$ MD simulations atrazine changes its orientation and binds in a deeper position inside the $Q_{\text {в }}$ pocket. In detail, only 5 amino acids (His215, Leu218, Phe255, Phe265 and Phe274) out of the 9 within $4 \AA$ distance from atrazine in the initial conformation, remained in the vicinity of atrazine at the end of the MD run. However, additional residues were found closer to the atrazine molecule (Phe211, Met214, Tyr246, Ile248, Ala251, Asn266, Asn267, Ser268, Leu271) (Figure 5).

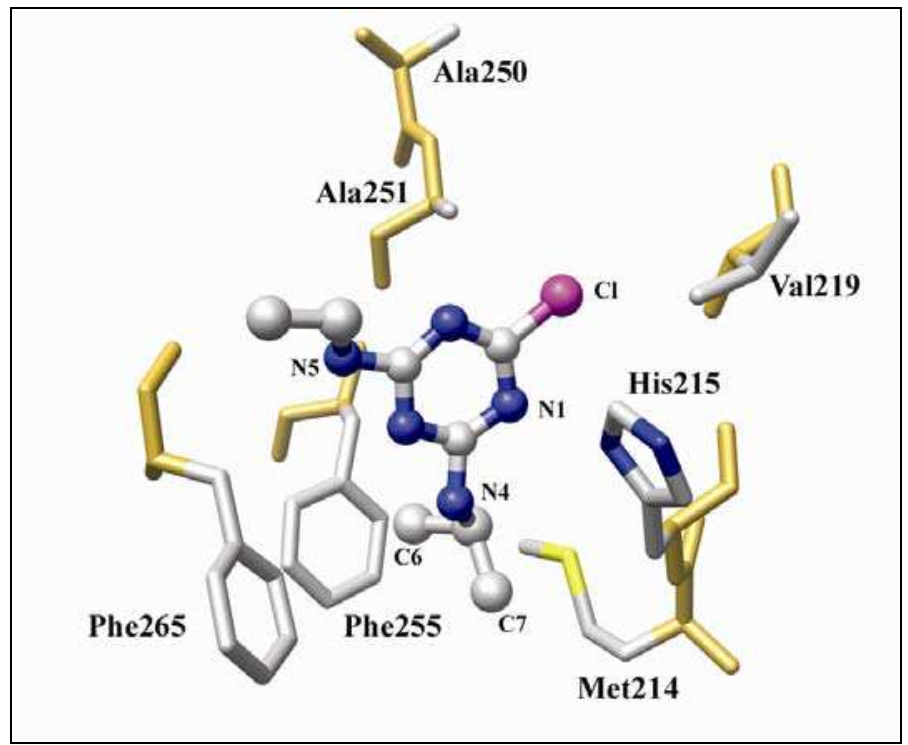

Fig. 5. Detailed representation of the chemical environment of the atrazine binding pocket after the MD simulations run. 
Analysis of the atrazine binding mode at the end of the simulation trajectory surprisingly reveals only few specific interactions with residues of the D1 protein which stabilize the bound molecule. In particular, hydrophobic interactions are observed between the C6 methyl group of atrazine and Phe255 phenyl ring, between the $\mathrm{C} 7$ methyl group of atrazine and the Met214 sidechain, while a single strong hydrogen bond is established between the $\mathrm{N} 1$ atom of atrazine and the His $215 \mathrm{~N} \delta$ proton. On the other end, apparently no binding partner stabilizes other groups on the atrazine molecule. In particular the chloride atom is bound in an energetically unfavorable position in the vicinity of the aliphatic residue Val219 and no hydrogen bonding partner is observed for the atrazine N4 and N5 protons. In two out of three cases, rational design of site-directed mutants are likely to increase atrazine affinity for the $Q_{B}$ binding niche. In fact, the atrazine chloride atom could be stabilized by mutation of Val219 into a polar residue that can provide a hydrogen bond donor to the chloride atom.

In the same way, the atrazine N5 proton could find a hydrogen bond partner through replacement of the aromatic Phe265 residue with a polar hydrogen bond acceptor.

Indeed, the results discussed above indicate that MD simulations can be an effective strategy for the design of an improved herbicide binding pocket in PSII and experiments are being carried out to evaluate the reliability of this approach.

\section{Relevance of genetic engineering to improve sensitivity and selectivity of biomediators for biosensor development}

The combination of computational analyses and molecular biology tools makes possible the realization of more stable, sensitive, selective and specific biomediators for the creation of effective biosensors. The improvement of these parameters is of outstanding relevance for biosensor reliability, and strongly attracts the interest of commercial companies accelerating the acceptance of this technology.

Nowadays, genetic engineering allows the modification of specific nucleotide sequences of an organism genome to obtain proteins with novel improved properties, and innovative biotechnological approaches make it possible to integrate these systems, or their functional sub-structures, into artificial assemblies for specific applications such as environmental monitoring. Several biomediators have been already developed exploiting molecular biological techniques to produce enzymes and/or protein with improved features in the detection of specific analytes (Wang et al., 2009).

In the context of the photosynthesis-based biosensors, activities in different research areas allowed the design and development of engineered photosynthetic microorganisms with improved sensitivity and stability features to be used as bio-recognition elements for the detection of environmental contaminants. Different approaches, such as space research and physical elicitations, have been applied to select microorganisms with improved tolerance to extreme environmental conditions. The newly selected organisms generated for biosensor purposes were able to maintain a stable photosynthetic efficiency and an increased oxygen evolution capacity (Rea et al., 2008).

In particular, we carried out modifications of the D1 reaction centre proteins, as they play a crucial role in electron tunnelling-mediated charge separation and transmembranal electric field generation, acting principally on reduction, release and migrations of (plasto) quinones. Random mutagenesis targeted to the D1-encoding $p s b \mathrm{~A}$ gene was exploited as a directed evolution strategy to produce a huge mutant library of chlamydomonas carrying 
novel D1 proteins with different aminoacidic composition. In addition, thanks to the support of bioinformatics studies, site-directed mutagenesis was also exploited to generate specific point mutations in the D1 protein, in order to modify the properties of the $\mathrm{PQ} /$ atrazine binding affinity.

Chlamydomonas D1 random and site-directed mutants were produced by particle gun bombardments of the chloroplast genome (Przibilla et al., 1991). The Del1 chlamydomonas strain was used as a recipient host for the mutant's generation (Preiss et al., 2001). This strain has a defined deletion in the chloroplast-encoded $p s b \mathrm{~A}$ gene and is unable to grow photoautotrophically, as it cannot produce a functional D1 protein. Acetate is needed as carbon source as minimal media do not support its growth. Minimal media were used to select photosynthetically active colonies generated after the integration of the $p s b \mathrm{~A}$ variant produced both by random and site-directed PCR (Dauvillee et al., 2004). Selected mutants were then characterised by analysing their photosynthetic performance and the sensitivity and/or resistance to different classes of herbicides assessed (Tibuzzi et al., 2007; Rea et al., 2009; Giardi et al., 2009; Scognamiglio et al., 2009). After the characterization, the best performing mutants were immobilized on screen-printed electrodes and integrated in amperometric or potentiometric circuits. Both electrochemical and optical devices were arranged in multi-arrayed setups.

\section{Biosensors already developed}

Although a variety of whole-cell-based bacterial sensors have been applied in environmental assays for pollutant monitoring, generally they display a poor response to herbicides (Table 3).

If the electron transfer from the reaction centre to the quinone pool is blocked, such as during the binding of the photosynthetically active pesticides, these parameters change dramatically and can be monitored by electro-optical analysis in a pesticide concentration dependent manner (Figure 6). In this context, an optical biosensor based on the green photosynthetic alga Chlamydomonas reinhardtii described by Tibuzzi and coworkers (2007) was employed to monitor several classes of herbicides, such as atrazine, diuron, ioxynil, terbuthylazine, prometryn and linuron, in a low concentration range $\left(10^{-8}-10^{-10} \mathrm{M}\right)$ (Table 3). In particular, a miniaturized optical biosensor instrument was designed and produced for multiarray fluorescence measurements of several biomediators in series, with applications in environmental monitoring and agrofood analysis. In the work by Rea and coworkers (2009), a computational study was performed to design and construct a set of mutant strains from the green photosynthetic alga $C$. reinhardtii, with higher sensitivity towards several classes and subclasses of herbicides (Table 3 ).

In this context, an in silico study was performed to predict mutations within the D1-D2 heterodimer which improve its specificity, sensitivity, and binding affinity for atrazine. In detail, taking advantage of the high sequence homology observed between Thermosynecococcus elongatus D1 and D2 proteins and the corresponding proteins from C. reinhardtii ( $87 \%$ and $89 \%$ amino acid sequence identity, respectively), the three-dimensional structure of the latter proteins was homology modelled. On the basis of this model, a series of D1 and D2 mutants were generated in silico and the atrazine affinity of wild type and mutant proteins was predicted by binding energy calculations to identify mutations able to increase PSII affinity for atrazine. 


\begin{tabular}{|c|c|c|c|}
\hline $\begin{array}{c}\text { DEVELOPED } \\
\text { BIOSENSORS }\end{array}$ & ADVANTAGES & DISADVANTAGES & REFERENCE \\
\hline $\begin{array}{l}\text { Whole-cell-based } \\
\text { bacterial biosensors } \\
\text { Cyanobacterial } \\
\text { PSII-based } \\
\text { biosensors }\end{array}$ & $\begin{array}{l}\text { - simple and rapid pre- } \\
\text { treatment steps } \\
\text { - real samples/complex } \\
\text { matrix analyses } \\
\text { - ability to recognize } \\
\text { different classes of chemicals }\end{array}$ & $\begin{array}{l}\text { - intrinsic instability, } \\
\text { short half-life and } \\
\text { specificity, poor } \\
\text { response }\end{array}$ & $\begin{array}{l}\text { Weitz et al., } 2001 \\
\text { Merz et al., } 1996\end{array}$ \\
\hline $\begin{array}{l}\text { Optical biosensor } \\
\text { based on various } \\
\text { microalgae or } \\
\text { chloroplast and } \\
\text { thylakoids } \\
\text { membranes }\end{array}$ & $\begin{array}{l}\text { - different recognition } \\
\text { elements for various classes } \\
\text { of pesticides, insecticides and } \\
\text { organophosphorus } \\
\text { compounds }\end{array}$ & $\begin{array}{l}\text { - high limits of } \\
\text { detection in a } \\
\text { concentration range } \\
\text { from } 10^{-8} \text { to } 10^{-3} \mathrm{M} \text { or } \\
10^{-9} \text { to } 10^{-5} \mathrm{M}\end{array}$ & $\begin{array}{l}\text { Marty et al., } 1995 \\
\text { Naessens et al., } \\
2000 \\
\text { Euzet et al., } 2005 \\
\text { Giardi et al., } 2005 \\
\text { Breton et al., } 2006\end{array}$ \\
\hline $\begin{array}{l}\text { Optical multiarray } \\
\text { biosensor which } \\
\text { employ several } \\
\text { mutant strains from } \\
\text { C. reinhardtii }\end{array}$ & $\begin{array}{l}\text { - high specificity towards } \\
\text { classes and subclasses of } \\
\text { herbicides } \\
\text { - low limits of detection in a } \\
\text { concentration range from } \\
10^{-10} \text { to } 10^{-8} \mathrm{M}\end{array}$ & $\begin{array}{l}\text { - low specificity } \\
\text { towards specific target } \\
\text { analytes }\end{array}$ & $\begin{array}{l}\text { Tibuzzi et al., } 2007 \\
\text { Rea et al., } 2009 \\
\text { Giardi et al., } 2009 \\
\text { Scognamiglio et } \\
\text { al., } 2009\end{array}$ \\
\hline $\begin{array}{l}\text { Biosensing } \\
\text { platform with } \\
\text { different } \\
\text { biomediators and } \\
\text { double detection } \\
\text { systems (optical } \\
\text { and amperometric) }\end{array}$ & $\begin{array}{l}\text { - high specificity towards } \\
\text { classes of herbicides } \\
\text { - low limits of detection in a } \\
\text { concentration range from } \\
10^{-10} \text { to } 10^{-8} \mathrm{M} \\
\text { - high stability of } \\
\text { immobilisation biological } \\
\text { recognition elements }\end{array}$ & $\begin{array}{l}\text { - low specificity } \\
\text { towards specific target } \\
\text { analytes }\end{array}$ & $\begin{array}{l}\text { Buonasera et al., } \\
2010\end{array}$ \\
\hline $\begin{array}{l}\text { Amperometric } \\
\text { biosensors based } \\
\text { on mutant strains } \\
\text { from C. reinhardtii }\end{array}$ & $\begin{array}{l}\text { - real samples/complex } \\
\text { matrix analyses }\end{array}$ & $\begin{array}{l}\text { - low specificity } \\
\text { towards specific target } \\
\text { analytes }\end{array}$ & Giardi et al., 2005 \\
\hline $\begin{array}{l}\text { Amperometric } \\
\text { biosensors based } \\
\text { on thylakoid from } \\
\text { Spinacia oleracea and } \\
\text { Senecio vulgaris }\end{array}$ & $\begin{array}{l}\text { - real samples/complex } \\
\text { matrix analyses }\end{array}$ & $\begin{array}{l}\text { - low specificity } \\
\text { towards specific target } \\
\text { analytes }\end{array}$ & $\begin{array}{l}\text { Touloupakis et al., } \\
2005\end{array}$ \\
\hline
\end{tabular}

Table 3. Main features of developed biosensors.

New advances in the same context were achieved in amplifying the range of recognition elements and measurement of a significant number of different classes of environmental pollutants. These advances occurred through the development of a biosensing system which uses sets of mutant organisms with different affinities towards pesticides. A library of functional mutations in the unicellular green alga $C$. reinhardtii for preparing biomediators was presented by Giardi and coworkers (2009). Exploiting bioinformatics to design new mutant strains resulted in the construction of microorganisms which showed different limits of detection for diazines, triazines and urea herbicides, underlined the high potential of bioinformatics and molecular biology in the design of desired biological material suitable for biosensor use. 


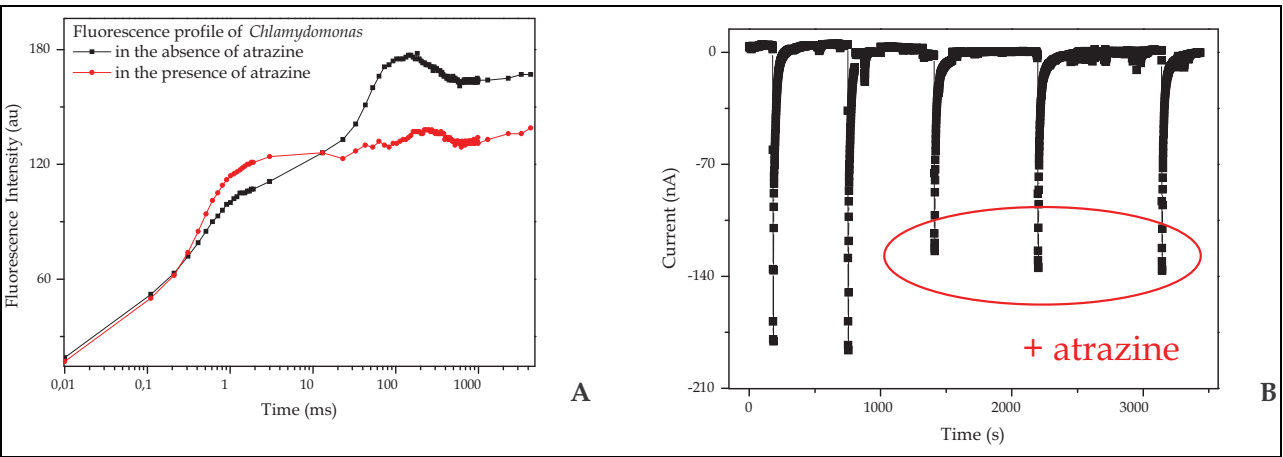

Fig. 6. (A) Fluorescence profile of $C$. reinhardtii PSII in the absence and in the presence of atrazine. The binding of the herbicide is related to the main parameters of the profile in a concentration dependent manner. (B) Current profiles of $C$. reinhardtii PSII in the absence and in the presence of atrazine $\left(10^{-7} \mathrm{M}\right)$. The binding of the herbicide decreases the current signal in a concentration dependent manner.

A multi-biomediator fluorescence biosensor based on a new versatile portable instrument was assembled by Scognamiglio and coworkers (2009). The biosensor instrument was composed of a 24 cell array configuration able to host different mutant strains for the detection of a variety of herbicide classes such as triazines, diazines and ureas (Figure 7).

As we can observe from the described advances in biosensor technology, the main features of a successful biosensor are characterised by the interchangeable recognition elements, which provide the versatility to measure large numbers of analytes. In Buonasera and coworkers (2010), a biosensing platform was constructed to provide an analytical tool applicable to the daily pre-screening of a broad spectrum of samples. The platform combined the most used transduction systems for biosensors, amperometric and optical systems, and used genetically modified microorganisms as versatile biomediators, allowing detection of different subclasses of herbicides.

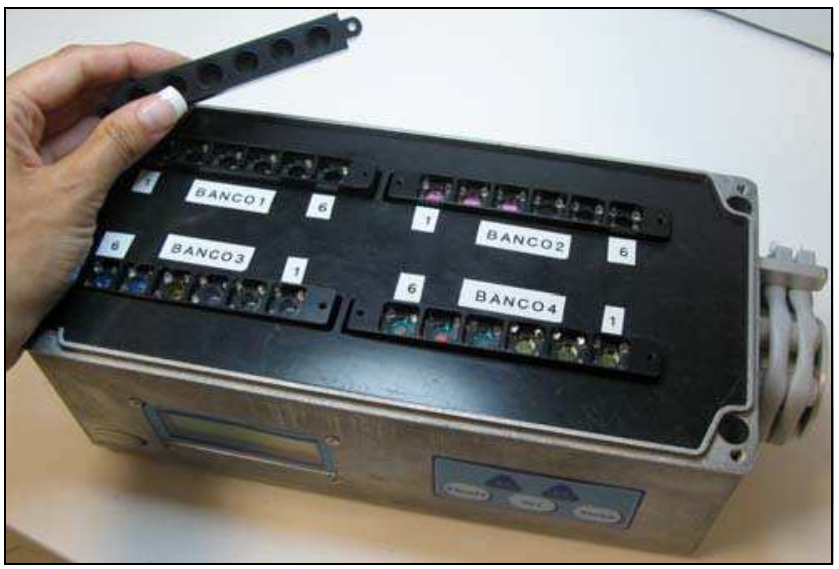

Fig. 7. Biosensing platform set-up consisting of 24 cells able to host an array of several biomediators. 
It represented a sensitive, reliable, and low-cost system able to detect water pollutants such as atrazine, diuron, linuron, and terbuthylazine down to 10-8-10-10 M. Combining the amperometric and optical detection systems, the platform was able to determine the toxicological potential of samples, through the determination of the biomediator physiological activity inhibition. Fluorescence modification and current reduction were related to the concentration of herbicide and quantified by a dedicated data acquisition software. In addition, the opportunity to use a wide range of biological materials made the platform a good candidate for the development of a biosensor with required features.

Several other practical aspects seem to be important for the development of biosensors. One of these aspects considers the variability of real samples, whose composition is usually unknown and can vary widely from sample to sample. Suitable biosensors have to demonstrate reliability in field tests followed by validation by standard analytical methodologies. In Giardi and coworkers (2005) a fluorescence multi-biosensor was reported based on the thylakoids activity from different microorganisms used for the determination of several pollutants on real samples from the Tiber river, the Aqua Marcia, the Valle del Sorbo, and the Po river, tested contemporaneously by gas chromatography-mass spectrometry. Similar results were found with both methods. In Touloupakis and coworkers (2005) an amperometric multibiosensor using various photosynthetic preparations as biosensing elements for the detection of herbicides and pollutants on real samples was described. The photosynthetic thylakoid from Spinacia oleracea, Senecio vulgaris and its mutant resistant to atrazine were immobilized on the surface of screen printed electrodes composed of a graphite-working electrode and $\mathrm{Ag} / \mathrm{AgCl}$ reference electrode deposited on a polymeric substrate (Figure 8). The presence of pollutants was revealed as the effect on PSII due to the sum of various herbicides, mainly triazines $(0.210 \mu \mathrm{g} / \mathrm{l})$ and phenolic compounds $(0.041 \mu \mathrm{g} / \mathrm{l})$. The performance of a biosensor is also related to the stability, the operating lifetime and the reusability of the biodevice, which is of critical importance and can affect the success of its use. In biosensor production, the biological material is usually immobilised, entrapped or cross-linked so as to produce an intimate connection or communication between the biomediator and the transducer. Many techniques have been

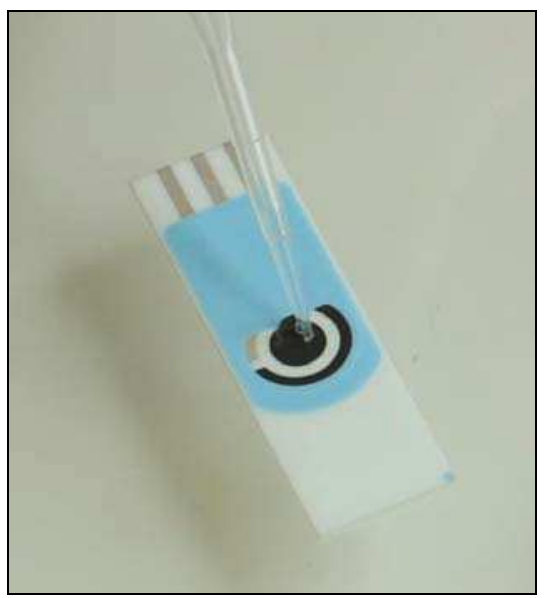

Fig. 8. Screen printed electrode used for biomediator immobilization. 
introduced to overcome manufacturing problems associated with stability. In Buonasera and coworkers (2010) different immobilisation procedures, following physical and chemical approaches, were described as being suitable for several biological recognition elements and to be applied in amperometric and/or fluorescence measurements, some of these biosensors are already commercially available (see www.biosensor.it) (Table 4).

\begin{tabular}{ccc}
\hline LEAKING & IMMOBILIZATION METHOD & $\begin{array}{c}\text { RESIDUAL } \\
\text { ACTIVITY \% }\end{array}$ \\
\hline High & Filter paper disk & 56 \\
High & Alumina filter disk & 26 \\
High & Glass microfiber filter & 49 \\
High & DEAE cellulose & 50 \\
Medium & Nitrocellulose & 90 \\
Medium & Agar & 45 \\
Medium & Agarose & 33 \\
Low & Carrageenan & 30 \\
Low & Alginate & 20 \\
Low & Gelatin & 50 \\
High & Lyophilisation & 70 \\
Low & Glutaraldehyde & 70 \\
Low & Magnetic-beads polymer & 60 \\
Low & Binding on gold films & 35 \\
Low & Collagen & 30 \\
Low & Bovine serum albumine (BSA-GA) & 70 \\
Low & Cross-linking on Gold & 20 \\
Low & Cross-linking on TiO 2 & 55 \\
Low & Polyacrylamid & 41 \\
Low & Polyurethane & 28 \\
Low & Photocrosslinkable resin & 10 \\
Low & Vinyl & 15 \\
Low & Poly(vinylalcohol) & 38 \\
Low & Tyrylpyridinium groups & 45 \\
Low & Thiophen polymer & 57 \\
& error less than 10\% & \\
\hline & Mow & \\
\hline
\end{tabular}

Table 4. Immobilization methods applied to several biomediators. The stability of each procedure was evaluated measuring the residual activity and leaking before and after immobilization.

\section{Conclusion and future perspectives}

The exploitation of herbicides for weed control is vital to increase the yields and productivity in agriculture. Without the use of herbicides, it would have been impossible to fully mechanize the production of cotton, sugar beets, grains, potatoes, and corn. As a consequence, given the harmful economic implications of poor harvesting, herbicide production is the principal driver of the farming industry. However, the continuous and massive application of these compounds can negatively affect human health and 
ecosystems. These consequences result in an increased demand for risk assessment and prompt the regulatory agencies to update legislation aimed at controlling environmental contaminations. In this scenario, the development of analytical devices able to detect the low levels of herbicide contaminants defined by the EU directives, and to distinguish among different classes of compounds, is essential. Several instruments which partially satisfying these requirements have been already developed.

Future activity should be focused on the development of new types of bio-sensing elements for building up a platform of modular biosensors which can be easily adopted for the simultaneous detection of several herbicides. We are currently manufacturing an array of novel whole-cell biosensors based on the activity of engineered photosynthesis enzymes with improved sensitivity and stability features, and ectopic expressed fluorescent proteins as sensing elements. The new complex biosensor array will be based on both optical and electronic transduction for multi-parameter detection. It will be able to monitor the herbicide levels and to diagnose their biological impact. This improvement should provide the impetus for the technological transfer from laboratory devices to in-field operation systems. The new devices will lead to a tremendous breakthrough in the detection of contaminants and quality control in risk assessment sectors by providing a rapid broad spectrum screening tool.

\section{Acknowledgements}

This study was granted by the EU FP7-SME-2008-1 projects: SENSBIOSYN n 232522 to GR; $B E E P-C-E N n^{\circ} 232082$ to MTG; MULTIBIOPLAT EUROTRANS-BIO-2007-34 to GR; CASPUR High-Performance-Computing Grants 2009-10 to FP.

\section{References}

Ackerman, F. (2007). The Economics of Atrazine. International Journal of Occupational and Environmental Health, 13: 441-449.

Al-Ahmad, H.; Galili, S. \& Gressel, J. (2005). Poor competitive fitness of transgenically mitigated tobacco in competition with the wild type in a replacement series. Planta, 222(2): 372-385.

Bouldin, J.L.; Farris, J.L.; Moore, M.T.; Smith, S. Jr. \& Cooper, C.M. (2006). Hydroponic uptake of atrazine and lambda-cyhalothrin in Juncus effusus and Ludwigia peploides. Chemosphere, 65: 1049-1057.

Brena, B.M.; Arellano, L.; Rufo, C.; Last, M.S.; Montaño, J.; Egaña Cerni, E.; GonzalezSapienza, G. \& Last, J.A. (2005). ELISA as an affordable methodology for monitoring groundwater contamination by pesticides in low-income countries. Environmental Science \& Technology, 39(11): 3896-3903.

Breton, F.; Euzet P.; Piletsky, S.A.; Giardi, M.T. \& Rouillon, R. (2006). Integration of photosynthetic biosensor with molecularly imprinted polymer-based solid phase extraction cartridge. Analytica Chimica Acta, 569: 50-57.

Buonasera, K.; Pezzotti, G.; Scognamiglio, V.; Tibuzzi, A. \& Giardi, M.T. (2010). New platform of biosensors for prescreening of pesticide residues to support laboratory analyses. Journal of Agricultural and Food Chemistry, 58(10): 5982-5990. 
Cavalcanti, A.; Shirinzadeh, B.; Freitas, R.A. \& Kretly, L.C. Jr. (2007). Medical nanorobot architecture based on nanobioelectronics. Recent Patents on Nanotechnology, 1(1): 110.

Cesnik, H.B.; Gregorcic, A.; Bolta, S.V. \& Kmecl, V. (2006). Monitoring of pesticide residues in apples, lettuce and potato of the Slovene origin, 2001-04. Food Additives and Contaminants, 23(2): 164-73.

Chouhan, R.S.; Rana, K.V.; Suri, C.R.; Thampi, R.K. \& Thakur, M.S. (2010). Trace-level detection of atrazine using immuno-chemiluminescence: dipstick and automated flow injection analyses formats. Journal of AOAC International, 93(1): 28-35.

Cox, C. (2001). Atrazine: Environmental contamination and ecological effects. Journal of Pesticide Reform, 21: 12-20.

Dauvillee, D.; Hilbig, L.; Preiss, S. \& Johanningmeier, U. (2004). Minimal extent of sequence homology required for homologous recombination at the psbA locus in Chlamydomonas reinhardtii chloroplasts using PCR-generated DNA Fragments. Photosynthesis Research, 79(2): 219-224.

DeVesa, S.S.; Blot W.J.; Stone, B.J.; Miller, B.A.; Tarone, R.E. \& Fraumeni, J.F. Jr. (1995). Recent cancer trends in the United States. Journal of the National Cancer Institute, 87(3): 175-182.

Duysens, L.N.M. \& Sweers, H.E. (1963). Mechanism of two photochemical reactions in algae as studied by means of fluorescence. In: Studies on Microalgae and Photosynthetic Bacteria, J. Ashida (Ed), 353-372, Tokyo University Press, Tokyo.

Environmental Protection Agency. (2009). Atrazine Science Reevaluation: Potential Health Impacts. EPA-HQ-OPP-2009-0759-0003 Accessed: October 27, 2009. www.epa.gov/pesticides/reregistration/atrazine/atrazine_update.htm.

EUROPEAN ECONOMIC COMMUNITY (EEC) 15 July 1991. Council Directive 91/414/ on the placing of plant protection products on the market. Official Journal of the European Communities, p. 1-290.

EUROPEAN ECONOMIC COMMUNITY (EEC) 27 June 1967. Council Directive 67/548/ on the approximation of laws, regulations and administrative provisions relating to the classification, packaging and labelling of dangerous substances. Official Journal of the European Communities, p. 196-198.

Eurostat statistical books. The use of plant protection products in the European Union. Data 1992-2003. [http://epp.euro stat.ec.europa.eu/cache/ITY_OFFPUB/KS-76-06669/EN/KS-76-06-669-EN.PDF].

EC REGULATION N. 2009/128/EC OF THE EUROPEAN PARLIAMENT AND OF THE COUNCIL 21 October 2009. Official Journal of the European Union. L 309/71-86.

EC REGULATION N. 149/2008 OF THE EUROPEAN COUNCIL 29 January 2008. Official Journal of the European Union. L 58/1-16.

EC REGULATION N. 396/2005 OF THE EUROPEAN PARLIAMENT AND OF THE COUNCIL 23 February 2005. Official Journal of the European Union. L 70/1-16.

Euzet, P.; Giardi, M.T. \& Rouillon, R. (2005). A crosslinked matrix of thylakoids coupled to the fluorescence transducer in order to detect herbicides. Analytica Chimica Acta, 539: 263-269. 
Fan, W.Q.; Yanase, T.; Morinaga, H.; Gondo, S.; Okabe, T.; Nomura, M.; Komatsu, T.; Morohashi, K.I.; Hayes, T.B.; Takayanagi, R. \& Nawata, H. (2007). Atrazine-induced aromatase expression is SF-1 dependent: implications for endocrine disruption in wildlife and reproductive cancers in humans. Environmental Health Perspectives, 115: 720-727.

Fawcett. (2008). Twenty years of university corn yield data: with and without atrazine, proceedings north central weed science society. North Central Weed Science Society.

Ferreira, K.N.; Iverson, T.M.; Maghlaoui, K.; Barber, J. \& Iwata, S. (2004). Architecture of the photosynthetic oxygen-evolving center. Science, 303: 1831-1838.

Forbush, B. \& Kok, B. (1968). Reaction between primary and secondary electron acceptors of photosystem II of photosynthesis. Biochimica et Biophysica Acta, 162: 243-253.

Frazier, L.M. (2007). Reproductive disorders associated with pesticide exposure. Journal of Agromedicine, 12(1): 27-37.

Frisch, M. J. et al., (2004). Gaussian 03, Revision C.02, Gaussian, Inc., Wallingford CT.

Fukuyama, T.; Tajima, Y.; Ueda, H.; Hayashi, K.; Shutoh, Y.; Harada, T. \& Kosaka, T. (2009). Allergic reaction induced by dermal and/or respiratory exposure to low-dose phenoxyacetic acid, organophosphorus, and carbamate pesticides. Toxicology, 261(3): 152-161.

Fussell, R.J.; Jackson Addie, K.; Reynolds, S.L. \& Wilson, M.F. (2002). Assessment of the stability of pesticides during cryogenic sample processing. 1. Apples. Journal of Agricultural and Food Chemistry, 50(3): 441-448.

Gascon, J.; Oubina, A. \& Barcelò, D. (1997). Detection of endocrine-disrupting pesticides by enzyme-linked immunosorbent assay (ELISA): application to atrazine. Trends in Analytical Chemistry, 16(10): 544-562.

Giardi, M.T.; Scognamiglio, V.; Rea, G.; Rodio, G.; Antonacci, A.; Lambreva, M.; Pezzotti, G. \& Johanningmeier, U. (2009). Optical biosensors for environmental monitoring based on computational and biotechnological tools for engineering the photosynthetic D1 protein of Chlamydomonas reinhardtii. Biosensor and Bioelectronics, 25(2): 294-300.

Giardi, M.T.; Guzzella, L.; Euzet, P.; Rouillon, R. \& Esposito, D. (2005). Detection of herbicide subclasses by an optical multibiosensor based on an array of photosystem II mutants. Environmental Science \& Technology, 39: 5378-5384.

Giardi, M.T. \& Pace, E. (2005). Photosynthetic proteins for technological applications. Trends in Biotechnology, 23(5): 257-263.

Giardi, M.T.; Marder, J.B. \& Barber, J. (1988). Herbicide binding to the isolated Photosystem II reaction centre. Biochimica et Biophysica Acta, 934: 64-71.

Green, J.M. \& Owen, M.D. (2010). Herbicide-Resistant Crops: Utilities and Limitations for Herbicide-Resistant Weed Management (dagger). Journal of Agricultural and Food Chemistry, DOI: 10.1021/jf101286h.

Gurney, J.G.; Davis, S.; Severson, R.K.; Fang, J.Y.; Ross, J.A. \& Robison, L.L. (1996). Trends in cancer incidence among children in the US. Cancer, 78: 532-541. 
Guskov, A.; Kern, J.; Gabdulkhakov, A.; Broser, M.; Zouni, A. \& Saenger1, W. (2009). Cyanobacterial photosystem II at $2.9-\mathrm{A}^{\circ}$ resolution and the role of quinones, lipids, channels and chloride. Nature Structural \& Molecular Biology, 16(3): 334-342.

Guzzella, L.; Pozzoni, F. \& Giuliano, G. (2006). Herbicide contamination of surficial groundwater in Northern Italy. Environmental Pollution, 142(2): 344-353.

Haworth, P. \& Steinback, K.E. (1987). Interaction of herbicides and quinone with the QBprotein of the diuron-resistant Chlamidomonas reinhardtii mutant Dr2. Plant Physiology, 83: 1027-1031.

Haynes, D.; Müller, J. \& Carter, S. (2000). Pesticide and herbicide residues in sediments and seagrasses from the great barrier reef world heritage area and queensland coast. Marine Pollution Bulletin, 41(7-12): 279-287.

Hilton, H.W.; Nomura, N.S.; Kameda, S.S. \& Yauger, W.L. (1976). Some patterns of herbicide and growth regulator intake, persistence, and distribution in sugarcane. Archives of Environmental Contamination and Toxicology, 4: 385-394.

Johanningmeier, U.; Sopp, G.; Brauner, M.; Altenfeld, U.; Orawski, G. \& Oettmeier, W. (2000). Herbicide resistance and supersensitivity in Ala250 or Ala251 mutants of the D1 protein in Chlamydomonas reinhardtii. Pesticide Biochemestry Physiology, 66: 9-19.

Kern, J. \& Renger, G. (2007). Photosystem II: Structure and mechanism of the water:plastoquinone oxidoreductase. Photosynthesis Research, 94: 183-202.

Kristensen, P.; Irgens, L.M.; Andersen, A.; Bye, A.S. \& Sundheim, L. (1997). Birth defects among offspring of Norwegian farmers, 1967-1991. Epidemiology, 8(5): 537-544.

Lancaster, C.R.D. \& Michel, H. (1999). Refined crystal structure of reaction centres from Rhoropseudomonas viridis in complexes with the herbicide atrazine and two chiral atrazine derivatives also lead to a new model of the bound carotenoid. Journal of Molecular Biology, 286: 883-898.

Lavergne, G. (1982). Mode of action of 3-(3,4 dichlorophenyl)-1,1 dimethylurea. Evidence that the inhibitor competes with plastoquinone for binding to a common site on the acceptor side of Photosystem II. Biochimica et Biophysica Acta, 682: 345-353.

Loh, K-S.; Lee, Y.H.; Musa, A.; Salmah, A.A. \& Zamri I. (2008). Use of Fe3O4 nanoparticles for enhancement of biosensor response to the herbicide 2,4-dichlorophenoxyacetic acid. Sensors, 8: 5775-5791.

Loll, B.; Kern, J.; Saenger, W.; Zouni, A. \& Biesiadka, J. (2005 a). Towards complete cofactor arrangement in the 3.0 A resolution structure of photosystem II . Nature, 438: 10401044.

Loll, B.; Kern, J.; Zouni, A.; Saenger, W.; Biesiadka, J. \& Irrgang, K.D. (2005 b). The antenna system of photosystem II from Thermosynechococcus elongatus at $3.2 \AA$ resolution. Photosynthesis Research, 86: 175-184.

Lorenzin, M. (2007). Pesticide residues in Italian Ready-Meals and dietary intake estimation. Journal of Environmental Science and Health. Part. B, Pesticides, food contaminants, and agricultural wastes, 42(7): 823-833.

Mage, D.T.; Allen, R.H.; Gondy, G.; Smith, W.; Barr, D.B. \& Needham, L.L. (2004). Estimating pesticide dose from urinary pesticide concentration data by creatinine correction in the Third National Health and Nutrition Examination Survey 
(NHANES-III). Journal of Exposure Analysis and Environmental Epidemiology, 14: 457465.

Marty, J.L.; Garcia, D. \& Rouillon, R. (1995). Biosensors: potential in pesticide detection. Trends in Analytical Chemistry, 14(7): 329-333.

Mazzei, F.; Botrè, F.; Lorenti, G.; Simonetti, G.; Porcelli, F.; Scibona, G. \& Botrè, C. (1995). Plant tissue electrode for the determination of atrazine. Analytica Chimica Acta, 316(1): 79-82.

McArdle, F.A. \& Persaud, K.C. (1993). Development of an enzyme-based biosensor for atrazine detection. Analyst, 118: 419-423.

Merz, D.; Geyer M.; Moss, D.A. \& Ache H.J. (1996). Chlorophyll fluorescence biosensor for the detection of herbicides. Fresenius' Journal of Analytical Chemistry, 354: 299-305.

Montesinos, E. (2003). Development, registration and commercialization of microbial pesticides for plant protection. International Microbiology, 6(4): 245-252.

Moreland, .D.E. \& Hill, K.L. (1962). Interference of herbicides with the Hill reaction of isolated chloroplasts. Weeds, 10: 229-236.

Moreland, D.E.; Gentner, J.L.; Hilton, J.L. \& Hill, K.L. (1959). Studies on the mechanism of herbicidal action of 2-chloro-4,6-bis(ethylamino)-s-triazine. Plant Physiology, 43: 432435.

Murphy, C.E. \& Lemerle, D. (2006). Continuous cropping systems and weed selection. Euphytica, 148: 61-73.

Naessens, M.; Leclerc, J.C. \& Tran-Minh C. (2000). Fiber optic biosensor using Chlorella vulgaris for determination of toxic compounds. Ecotoxicology and Environmental Safety, 46: 181-185.

Ochoa-Acuña, H.; Frankenberger, J.; Hahn, L. \& Carbajo, C. (2009). Drinking-water herbicide exposure in Indiana and prevalence of small-for-gestational-age and preterm delivery. Environmental Health Perspectives, 117: 1619-1624.

Oettmeier, W. (1999). Herbicide resistance and supersensitivity in photosystem II. Cellular and Molecular Life Sciences: 55: 1255-1277.

Oettmeier, W.; Kude, C. \& Soll, H-J. (1987). Phenolic herbicides and their methylethers: binding characteristics and inhibition of photosynthetic electron transport and photophosphorylation. Pesticide Biochemistry Physiology, 27: 50-60.

Oettmeier, W. \& Masson, K. (1980). Synthesis and thylakoid membrane binding of the radioactively labeled herbicide dinoseb. Pesticide Biochemistry Physiology, 14: 86-97.

Paris, P.; De santis, T.; Esposito, D.; Giuliani, R. \& Pace, E. (2009). Atti del XVII convegno S.I.R.F.I. Protezione dei corpi idrici superficiali dall'inquinamento da agro-farmaci. Vidotto, F. ; Ferrero, A. (Eds.), 17-35, Bologna, Italy, (ISBN 978-88-95616- 49802-5).

Pfister, K.; Steinback, K.K.; Gardner, G. \& Arntzen, C.J. (1981). Photoaffinity labelling of a herbicide receptor in chloroplast membranes. Proceedings of the National Academy of Sciences of the United States of America, 78: 981-985.

Pfister, K. \& Arntzen, C.J. (1979). The mode of action of Photosystem II-specific inhibitors in herbicide-resistant weed biotypes. Zeitschrift für Naturforschung. C, Journal of Biosciences, 34: 996-1009.

Pfister, K.; Radosevich, S.R. \& Arntzen, C.J. (1979). Modification of herbicide binding to photosystem II in two biotypes of Sencio vulgaris L. Plant Physiology, 78: 981-985. 
Preiss, S.; Schrader, S. \& Johanningmeier, U. (2001). Rapid, ATP-dependent degradation of a truncated D1 protein in the chloroplast. European Journal of Biochemistry, 268(16): 4562-4569.

Przibilla, E.; Heiss, S.; Johanningmeier, U. \& Trebst, A. (1991). Site-specific mutagenesis of the D1 subunit of photosystem II in wild-type chlamydomonas. The Plant Cell, 3: 169-174.

RB-159R Biosensors and Bioelectronics report released by Business Communications Co., Inc. (bccresearch.com)

Rea, G.; Antonacci, A.; Lambreva, M.; Margonelli, A.; Ambrosi, C. \& Giardi M.T. The NUTRA-SNACKS project: basic research and biotechnological programs on nutraceutics. In: Bio-Farms for Nutraceuticals: Functional Food and Safety Control by Biosensors. Editors: M.T. Giardi, G. Rea \& B. Berra. Landes Bioscience, Springer Publishers, Church St. Georgetown USA. In press.

Rea, G.; Polticelli, F.; Antonacci, A.; Scognamiglio, V.; Katiyar, P.; Kulkarni, S.A.; Johanningmeier, U. \& Giardi, M.T. (2009). Structure-based design of novel Chlamydomonas reinhardtii D1-D2 photosynthetic proteins for herbicide monitoring. Protein Science, 18(10): 2139-2151.

Rea, G.; Serafini, A.; Margonelli, A.; Faraloni, C.; Zanini, A.; Bertalan, I.; Johanningmeier, U. \& Giardi. M.T. (2008). Ionizing radiation impacts photochemical quantum yield and oxygen evolution activity of photosystem II in photosynthetic microorganisms. International Journal of Radiation Biology, 84 (11): 867-877.

Readman, J.W.; Albanis, T.A.; Barcelo, D.; Galassi, S.; Tronczynski, J. \& Gabrielides, G.P. (1993). Herbicide contamination of Mediterranean estuarine waters: results from a MED POL pilot survey. Marine Pollution Bulletin, 26 (11): 613-619.

Relyea, R.A. (2005). The impact of insecticides and herbicides on the biodiversity and productivity of aquatic communities. Ecological Applications, 15(2): 618-627.

Renger, G. (1986). Herbicide interaction with Photosystem II: recent developments. Physiologie Végétale, 24: 509-521.

Ries, L.A.G.; Kosary, C.L.; Hankey, B.F.; Miller, B.A.; Clegg, L.; \& Mariotto, A.; et al. (1998). SEER Cancer Statistics Review, 1973-1995. NIH Publ no 98-2789. Bethesda, MD: National Cancer Institute.

Roberts, D.M.; Buckley, N.A.; Mohamed, F.; Eddleston, M.; Goldstein, D.A.; Mehrsheikh, A.; Bleeke, M.S. \& Dawson, A.H. (2010). A prospective observational study of the clinical toxicology of glyphosate-containing herbicides in adults with acute selfpoisoning. Clinical Toxicology (Philadelphia, Pa.), 48(2): 129-136.

Sass, J.B. \& Colangelo, A. (2006). European Union bans atrazine, while the United States negotiates continued use. International Journal of Occupational and Environmental Health, 12(3): 260-267.

Shewry, P.R.;Jones, H.D. \& Halford, N.G. (2008). Plant biotechnology: transgenic crops. Advances in Biochemical Engineering/Biotechnology; 111: 149-186.

Schneider, M.I.; Sanchez, N.; Pineda, S.; Chi, H. \& Ronco, A. (2009). Impact of glyphosate on the development, fertility and demography of Chrysoperla externa (Neuroptera: Chrysopidae): ecological approach. Chemosphere; 76(10): 1451-1455. 
Schreinemachers, D.M. (2010). Perturbation of lipids and glucose metabolism associated with previous 2,4-D exposure: a cross-sectional study of NHANES III data, 19881994. Environmental Health, 9: 11.

Scognamiglio, V.; Raffi, D.; Lambreva, M.; Rea, G.; Tibuzzi, A.; Pezzotti, G.; Johanningmeier, U. \& Giardi, M.T. (2009). Chlamydomonas reinhardtii genetic variants as probes for fluorescence sensing system in detection of pollutants. Analytical and Bioanalytical Chemistry, 394(4): 1081-1087.

Senthilselvan, A.; McDuffie, H.H. \& Dosman, J.A. (1992). Association of asthma with use of pesticides. Results of a cross-sectional survey of farmers. The American Review of Respiratory Disease, 146(4): 884-887.

Shao, C. Y.; Howe, C. J.; Porter, A. J. R. \& Glover, L. A. (2002). Novel cyanobacterial biosensor for detection of herbicides. Applied and Environmental Microbiology, 68(10): 5026-5033.

Shimabukuro, R.H. \& Swanson, H.R. (1969). Atrazine metabolism, selectivity, and mode of action. Journal of Agriculture and Food Chemistry, 17: 199-204.

Siu, S.W.I.; Vacha, R.; Jungwirth P. \& Böckmann, R. A. (2008). Biomolecular simulations of membranes: physical properties from different force fields. The Journal of Chemical Physics, 128: 125103.

Sondhia, S. (2010). Persistence and bioaccumulation of oxyfluorfen residues in onion. Environmental Monitoring and Assessment, 162: 163-168.

Swanton, C. J.; Gulden, R. H. \& Chandler, K. (2007). A rationale for atrazine stewardship in corn. Weed Science, 55: 75-81.

Takahashi, T.; Inoue-Kashino, N.; Ozawa, S.; Takahashi, Y.; Kashino, Y. \& Satoh, K. (2009). Photosystem II complex in vivo is a monomer. The Journal of Biological Chemistry; 284: 15598-15606.

Tanner, C.M.; Ross, G.W.; Jewell, S.A.; Hauser, R.A.; Jankovic, J.; Factor, S.A.; Bressman, S.; Deligtisch, A.; Marras, C.; Lyons, K.E.; Bhudhikanok, G.S.; Roucoux, D.F.; Meng, C.; Abbott, R.D. \& Langston, J.W. (2009). Occupation and risk of parkinsonism: a multicenter case-control study. Archives of Neurology, 66(9): 1106-1113.

Thevenot, D.R.; Tóth, K.; Durst, R.A. \& Wilson G.S. (1999). Electrochemical biosensors: recommended definitions and classification. Pure and applied chemistry. Chimie Pure et Appliquée Links, 71: 2333-2348.

Tibuzzi, A.; Rea, G.; Pezzotti, G.; Esposito, D.; Johanningmeier, U. \& Giardi, M.T. (2007). A new miniaturized multiarray biosensor system for fluorescence detection. Journal of Physics: Condensed Matter, 19: 395006-395018.

Tischer, W. \& Strotmann, H. (1977). Relationship between inhibitor binding by chloroplasts and inhibition of photosynthetic electron transport. Biochimica et Biophysica Acta, 460: 113-125.

Touloupakis, E.; Giannoudi, L.; Piletsky, S.A.; Guzzella, L.; Pozzoni, F. \& Giardi, M.T. (2005). A multi-biosensor based on immobilized Photosystem II on screen-printed electrodes for the detection of herbicides in river water. Biosensor $\mathcal{E}$ Bioelectronics, 20(10): 1984-1992. 
Trebst, A. (1987). The three-dimenstional structure of the herbicide binding niche on the reaction center polypeptides of photosystem II. Zeitschrift für Naturforschung. C, Journal of Biosciences, 42c: 742-750.

Trebst, A. (1986). The topology of the plastoquinone and herbicide binding peptides of Photosystem II in the thylakoid membrane. Zeitschrift für Naturforschung. C, Journal of Biosciences, 41c: 240-245.

Turner, M.C.; Wigle, D.T. \& Krewski, D. (2010). Residential pesticides and childhood leukemia: a systematic review and meta-analysis. Environmental Health Perspectives, 118: 33-41.

US Environmental Protection Agency (US EPA). (1994). Atrazine, simazine and cyanazine, notice of initiation of special review. Federal Register, 59: 60412-60443.

Van der Spoel, D.; Lindahl, E.; Hess, B.; Groenhof, G.; Mark, A.E. \& Berendsen, H.J.C. (2005). GROMACS: fast, flexible and free. Journal of Computational Chemistry, 26: 1701-1718.

Van Rensen, J.J.S. (1982). Molecular mechanisms of herbicide action near photosystem II. Physiol Plantarum, 54: 515-521.

Vermaas, W.F.J.; Arntzen, C.J.; Gu, L.Q. \& Uy, C.A. (1983). Interactions of herbicides and azidoquinones at a photosystem II binding site in the thylakoid membrane. Biochimica et Biophysica Acta, 723: 266-275.

Vila-Aiub, M.M.; Vidal, R.A.; Balbi, M.C.; Gundel, P.E.; Trucco, F. \& Ghersa, C.M. (2008). Glyphosate-resistant weeds of South American cropping systems: an overview. Pest Management Science, 64(4): 366-371.

Waller, S.A.; Paul, K.; Peterson, S.E. \& Hitti, J.E. (2010). Agricultural-related chemical exposures, season of conception, and risk of gastroschisis in Washington State. American Journal of Obstetrics and Gynecology, 202: 241.

Wang, H.; Nakata, E. \& Hamachi I. (2009). Recent progress in strategies for the creation of protein-based fluorescent biosensors. Chembiochem : a European Journal of Chemical Biology, 10(16): 2560-2577.

Wang, J.; Wolf, R.M.; Caldwell, J.W.; Kollamn, P.A. \& Case, D.A. (2004). Development and testing of a general Amber force field. Journal of Computational Chemistry, 25: 11571174.

Wang, J.; Wang, W.; Kollman P. A. \& Case, D. A. (2006). Automatic atom type and bond type perception in molecular mechanical calculations. Journal of Molecular Graphics and Modelling, 25: 247260-247280.

Wang, J.; Cieplak, P. \& Kollman P.A. (2000). How well does a restrained electrostatic potential (RESP) model perform in calculating conformational energies of organic and biological molecules?. Journal of Computational Chemistry, 21: 1049-1074.

Weitz, H.J.; Ritchie J.M.; Bailey, D.A.; Horsburgh A.M.; Killham K. \& Glover, L.A. (2001). Construction of a modified mini-Tn5 luxCDABE transposon for the development of bacterial biosensors for ecotoxicity testing. FEMS Microbiology Letters, 197: 159-165.

Weselak, M.; Arbuckle, T.E.; Wigle, D.T.; Walker, M.C. \& Krewski, D. (2008). Pre- and postconception pesticide exposure and the risk of birth defects in an Ontario farm population. Reproductive Toxicology (Elmsford, N.Y.), 25(4): 472-480.

Williams, M.M.; Boerboom, C.M. \& Rabaey, T.L. (2010). Significance of atrazine in sweet corn weed management systems. Weed Technology, 24: 139-142. 
Williams, M.M.; Davis, A.S.; Rabaey, T.L. \& Boerboom, C.M. (2009). Linkages among agronomic, environmental, and weed management characteristics in North American sweet corn production. Field Crops Research, 113: 161-169.

Witte, I.; Jacobi, H. \& Juhl-Strauss, U. (1995). Correlation of synergistic cytotoxic effects of environmental chemicals in human fibroblasts with their lipophilicity. Chemosphere, 31(9): 4041-4049.

Xiong, J.; Govindjee, J. \& Subramaniam, S. (1996). Modeling of the D1/D2 proteins and cofactors of the Photosystem II reaction center: Implications to herbicide and bicarbonate binding. Protein Science, 5: 2054-2073.

Zahm, S. \& Ward, M. (1998). Pesticides and Childhood Cancer. Environmental Health Perspectives, 106(3): 893-908. 




\author{
Herbicides, Theory and Applications \\ Edited by Prof. Marcelo Larramendy
}

ISBN 978-953-307-975-2

Hard cover, 610 pages

Publisher InTech

Published online 08, January, 2011

Published in print edition January, 2011

The content selected in Herbicides, Theory and Applications is intended to provide researchers, producers and consumers of herbicides an overview of the latest scientific achievements. Although we are dealing with many diverse and different topics, we have tried to compile this "raw material" into three major sections in search of clarity and order - Weed Control and Crop Management, Analytical Techniques of Herbicide Detection and Herbicide Toxicity and Further Applications. The editors hope that this book will continue to meet the expectations and needs of all interested in the methodology of use of herbicides, weed control as well as problems related to its use, abuse and misuse.

\title{
How to reference
}

In order to correctly reference this scholarly work, feel free to copy and paste the following:

Giuseppina Rea, Fabio Polticelli, Amina Antonacci, Maya Lambreva, Sandro Pastorelli, Viviana Scognamiglio, Veranika Zobnina and Maria Teresa Giardi (2011). Computational Biology, Protein Engineering, and Biosensor Technology: a Close Cooperation for Herbicides Monitoring, Herbicides, Theory and Applications, Prof. Marcelo Larramendy (Ed.), ISBN: 978-953-307-975-2, InTech, Available from: http://www.intechopen.com/books/herbicides-theory-and-applications/computational-biology-proteinengineering-and-biosensor-technology-a-close-cooperation-for-herbicide

\section{INTECH}

open science | open minds

\author{
InTech Europe \\ University Campus STeP Ri \\ Slavka Krautzeka 83/A \\ 51000 Rijeka, Croatia \\ Phone: +385 (51) 770447 \\ Fax: +385 (51) 686166 \\ www.intechopen.com
}

\author{
InTech China \\ Unit 405, Office Block, Hotel Equatorial Shanghai \\ No.65, Yan An Road (West), Shanghai, 200040, China \\ 中国上海市延安西路65号上海国际贵都大饭店办公楼405单元 \\ Phone: +86-21-62489820 \\ Fax: +86-21-62489821
}


(C) 2011 The Author(s). Licensee IntechOpen. This chapter is distributed under the terms of the Creative Commons Attribution-NonCommercialShareAlike-3.0 License, which permits use, distribution and reproduction for non-commercial purposes, provided the original is properly cited and derivative works building on this content are distributed under the same license. 